In Narvaez, D., Panksepp, J., Schore, A., \& Gleason, T. (Eds.) (2013). Evolution, Early Experience and Human

Development: From Research to Practice and Policy. New York: Oxford University Press.

\title{
The Value of Using an Evolutionary Framework for Gauging Children’s
}

\section{Well-Being}

Darcia Narvaez, Jaak Panksepp, Allan Schore, and Tracy Gleason

Earlier conceptions of the essential nature of developmental experiences found axiomatic that “early childhood is destiny.” This view was deeply embedded in two paradigms—psychoanalysis under the Freudian view, which emphasized parenting influences, and behaviorism, which emphasized early conditioning and reinforcement history (although both psychoanalytic psychotherapists and behaviorists assumed that patterns could be unlearned with some effort). When developmental psychology changed in paradigm to an ecological system perspective that acknowledges multiple levels of influence (Bronfenbrenner, 1979), emphasis shifted to a focus on human resiliency in the face of risk factors (Lester, Masten, \& McEwen, 2007). Neuroscience has bolstered the resilient view of development with evidence that the brain remains plastic throughout the life span (e.g., Doidge, 2007; Merzenich et al., 1996). Early childhood is thus viewed within the prism of lifelong interactions among ecosystems and individual neuroaffective propensities, highlighting developmental person-by-context interactions and abundant individual variability in emotional resilience (Suomi, 2006; Worthman, Plotsky, Schechter, \& Cummings, 2010).

In the enthusiasm to embrace ideas of life span resiliency, psychology has often softpedaled the lasting neurobiological influences of early childhood experience. When researchers have documented the remarkable resiliency of children (e.g., Lester et al., 2007), they often point to better outcomes than might be predicted from certain preclinical studies of early 
developmental trajectories (Kagan, 1997). In a way, resiliency literature focuses on "good enough” development. As long as children do not end up, for example, as dropouts or inmates, their development is termed a success. Many psychologists and parents seem satisfied with resiliency as a goal for child development. But trends for such outcomes are not always positive. A decade ago, one in four teenagers in the United States was at risk for a poor life outcome (Eccles \& Grootman, 2002), and in recent analyses such trends have not improved (Heckman, 2008). The national prevalence of young children (under 5 years) with psychosocial problems has been on the increase to between 10\% and 21\% (Powell, Fixen, \& Dunlop, 2003). The rates of young children whose behavior displays aggression, delinquency, or hyperactivity are on the increase, at times estimated to be as high as $25 \%$ (Raver \& Knitze, 2002). The American Academy of Childhood and Adolescent Psychiatry is now describing a “crisis” in children’s mental health: 1 in every 5 children has a diagnosable psychiatric disorder, and 1 in every 10 suffers from a mental illness severe enough to impair everyday living (American Academy of Child and Adolescent Psychiatry, 2011). These epidemiological data, as well as recent psychiatric and neurobiological research, seriously challenge the concept of universal resilience, suggesting it may be misleading, simplistic, and incorrect (e.g., Hardwired to Connect, 2003; Lanius, Vermetten, \& Pain, 2010; Schore, 2003; Szajnberg, Goldenberg, \& Hatari, 2010).

Another reason to be concerned about the current developmental psychological conception of resilience comes from recent research, which is tempering views that the faults of early childhood can be easily outgrown. Indeed, many cannot be, or if they can, the process requires serious and considerable intervention (Perry, Pollard, Blakely, Baker, \& Vigilante, 1995; Schore, 1994, 2001a). The evidence across animal, human psychological, neurobiological, and anthropological research is increasing and converging to demonstrate lifetime vulnerability 
of brain and body systems among those with poor early care. Even when medicines are available to alleviate symptoms of dysfunction, the underlying suboptimal structures remain. This problem may be particularly true for emotional and moral functioning (Narvaez, 2008).

A host of public, personal, and social health problems that may have their roots in early experience have been skyrocketing in the United States and increasingly around the world (e.g., psychological problems such as attention deficit/hyperactivity disorder, autism, anxiety, and depression, not to mention psychosomatic conditions such as diabetes, hypertension, and a variety of autoimmune disorders; see, e.g., Felitti \& Anda, 2005; Sanchez, Ladd, \& Plotsky, 2001; U.S. Department of Health and Human Services, Substance Abuse and Mental Health Services Administration, 1999; World Health Organization and World Organization of Family Doctors, 2008). Although considerable progress is now being made, science does not have a complete understanding or consistent reliable remedies, nor preventive strategies, for addressing these rising problems.

The emergence and spread of the affective and social neurosciences (Cacioppo \& Bernsten, 1992; Panksepp, 1998, 2005) make this an auspicious time to reconsider the early life needs of human mammalian systems in light of fostering optimal development (Worthman et al., 2010). This research has provided a greater focus on intrinsic aspects of social functioningespecially primary emotional neuro-affective processes that may need to be enhanced. These disciplines have helped identify the types of brain functions that are typically found in mammalian brains, but they have not scientifically specified how these functions are normally (under conditions of optimal development) expressed in humans (but see Schore, 2001b). Nor do we know how they develop and become modified by cultural practices. Without a clear vision of how the emotional foundations of human brains develop and function, psychological science will 
not be well grounded in scientifically established evolutionary principles (Meaney, this volume; Panksepp, 2010).

\section{The Emotional Foundations of Brain Development, Thought, and}

\section{Behavior}

Affective neuroscience research has specified some of the subcortical anatomies and neurochemistries of basic emotional systems that constitute ancestral memories for a few of the most important feelings that guide human and animal existence (see Panksepp, 1998, for a review). Basic emotion systems constitute genetically ingrained psychobehavioral potentials that help an animal behave adaptively. These potentials are shaped by experience, influencing the functioning of both subcortical and neocortical structures that regulate communication quality (e.g., prosody) and guide adaptive responses to life events (Zinken, Knoll, \& Panksepp, 2008). The healthy integration of the lower primary-process emotional-affective powers of the mind and the emergent secondary (learning) and tertiary (thoughtful) cognitive landscapes are left to environmental influences, especially to families and the surrounding cultural milieus (see Worthman et al., 2010).

Developmental science has highlighted sensitive periods in mammalian emotional, social, and cognitive functioning (e.g., Nelson \& Panksepp, 1998; Schore, 1994). Only a few of these developmental programs are well mapped in animal models (e.g., vision and other sensory systems, as well as social bonding in several species); fewer still are mapped in the human species (e.g., language), and most cannot be, except for a few psychophysiological correlates of neural activities (e.g., functional magnetic resonance imaging). For ethical reasons, in the domain of emotions, we must resort to animal models to obtain generalizable primary- and secondary-process neurobiological principles relevant to the human condition (LeDoux, 1996; 
Panksepp, 1998, 2005, 2010). Fortunately, a great deal of evidence now indicates impressive homologies in subcortically concentrated, genetically provided emotional and motivational systems (i.e., key brain areas and chemistries) among all mammals that have been studied; these have substantial cross-species consistencies with abundant predictive robustness in psychiatrically oriented preclinical research (Panksepp \& Harro, 2004). ${ }^{1,2}$

\section{The Environment of Evolutionary Adaptedness and Mammalian Needs}

Mammals require abundant nurturing care for optimal postnatal development (Weaver, Szyf, \& Meaney, 2002). Catarrhine mammals in particular require profound social care (Konner, 2010).

${ }^{1}$ Other animals, such as birds, have developed in similar directions (Orosz \& Bradshaw, 2007).

${ }^{2}$ Still, the claim of homologies between humans and other animals needs to be made with certain qualifications. Diversity is the hallmark of evolution as different species adapted to different ecological niches (for a review see, West-Eberhard, 2003), so no details of basic emotional and motivational systems are identical across any species (Panksepp, 1998). Moreover, abundant rapidly responding epigenetic effects as well as regulation of protein synthesis by microRNAs distinguish individuals with identical structural genes (e.g., Szyf, McGowan \& Meaney, 2008). However, differences in details rarely reflect differences in underlying principles. For instance, oxytocin is now recognized as a brain chemical that helps regulate social bonding in many mammals (Carter, 1998, 2003; Insel, Gingrich, \& Young, 2002<AQ: Changed Inset et al. to Insel, Gingrich, \& Young to match references-as meant? THIS IS FINE>; Nelson \& Panksepp, 1998) with some unique implications and predictions for humans (Panksepp, 2009). At the same time, brain opioids and the ancestral nonapeptide arginine-vasotocin, with a single amino acid difference from oxytocin, carries out homologous functions in birds, such as robust inhibition of separation distress (Panksepp, 1998). 
John Bowlby (1951; following Hartman, 1939), psychiatrist-turned-ethologist who created attachment theory, conceptualized the deep human need for profuse sociality as a consequence of our ancestral "environment of evolutionary adaptedness" (EEA; Bowlby, 1951), the sum of environmental characteristics under which human brains and bodies evolved. We can assume these needs took a specific form when the human genus emerged from ancestral great apes to develop cultural practices that appear to have remained largely stable for $99 \%$ of human genus history (e.g., Fry, 2006, 2009). Most of these practices evolved with catarrhine mammals more than 30 million years ago (Konner, 2010). In modern societies, the ancient practices that presumably sustained an implicit understanding of the needs of "the mammalian” brain-mind have been supplanted by "advanced" cultural practices that may be losing touch with our ancestral needs. Thus, we are integrating several literatures—including mammalian animal models and anthropological visions of our evolutionary heritage and evolved, expected care in early life.

Our evolutionary heritage has most often been described in relation to early life experience even though it was experienced over the course of a lifetime. Thus far, scientists have focused primarily on evolved, expected care during infancy and early childhood largely because of confidence that these early phases are more tightly linked to primary-process, primordial biological adaptations rather than to tertiary-process cultural elaborations (but see Levine et al., 1994, for a review emphasizing enculturation in parenting; and see Lumsden \& Wilson, 1981, for the influence of culture on fitness-enhancing genetic adaptations). Substantive evidence, albeit indirect, comes from extant studies of foraging communities around the world, as anthropologists summarize the best current evidence of evolved, expected care for optimal 
development of infants and young children (e.g., Hewlett \& Lamb, 2005). According to the review of findings:

[Y]oung children in foraging cultures are nursed frequently; held, touched, or kept near others almost constantly; frequently cared for by individuals other than their mothers (fathers and grandmothers, in particular) though seldom by older siblings; experience prompt responses to their fusses and cries; and enjoy multiage play groups in early childhood. (Hewlett \& Lamb, 2005, p. 15)

These characteristics generally match the early experiences of highly social mammals, especially apes.

In this chapter, we use an evolutionary framework that includes our evolutionary heritage, sometimes referred to as the "environment of evolutionary adaptedness" (EEA), along dimensions relevant today, to examine early-life-experience effects. We discuss several of these early childrearing characteristics in light of related scientific studies and current practices as known. For most practices, research has not identified exactly when and to what extent compromises of evolved, expected care causes problems. Moreover, these compromises may differ as a function of timing, intensity, length, and context (to name a few variables; also see Davis \& Sandman, 2010; Lupien, McEwen, Gunnar, \& Heim, 2009). Nevertheless, research reviewed in this volume points to problematic or less than optimal outcomes when these general principles are violated.

\section{Natural Childbirth}

Current birthing and childrearing practices no longer come close to the traditional practices of evolved, expected care (see Trevathan, 2011; this volume). Specifically, in the course of childbirth, mammalian parents typically follow the natural rhythms of the mother and child that 
obviously never involved the many current medical interventions that are common. In contrast, current human societal practices induce physical pain in infants through a variety of perinatal practices, some of which began in an era when when infants were presumed to feel no pain. Since World War II, most children in the United States have been born in hospitals (Devitt, 1977), where birth has been medicalized and obstetric practices are the most intrusive in the world, sometimes increasing risks to infants and mothers that lead to high rates of mortality for both groups (Wagner, 2006). Cesarean birth, although sometimes vital for the survival of both mother and baby, now accounts for over 31\% of births in the United States (Hamilton, Martin, \& Ventura, 2009). Cesarean birth interferes with physiological responsiveness in the mother to the newborn (Swain, Tasgin, Mayes, Feldman, \& Leckman, 2008), circumventing the ecstatic wash of hormones that typically accompanies natural vaginal birth (Klaus \& Kennel, 1976). Hopefully now mostly in the past, hospitals employed harsh birthing practices (e.g., spanking, separation of mother and child) and imposed such things as bright lights, noxious odors, and painful procedures on neonates, all of which can have detrimental effects on development (see Liu et al., 2007, for a review). Still other current practices also affect later development: Gestational ultrasounds can influence neuronal migration (Ang, Gluncic, Duque, Schafer, \& Rakic, 2006), and circumcision obviously causes considerable pain and can impair biological functions (Anders \& Chalemian, 1974; Emde, Harmon, Metcal, Koenig, \& Wagonfeld, 1971) and social responsivity and attachments (Marshall et al., 1982). And stress, such as that induced by medical birth practices, may foster brain changes that can become permanent if their duration is intense, long, or unmitigated (Lanius et al., 2010). Consequently, common practices around birth in the United States may be disrupting mother-infant entrainment and affecting optimal emotional and social development. What is more, birth experiences can influence mother-child bonding and 
subsequent breastfeeding success (Klaus \& Kennel, 1976; Trevarthen, 1987, this volume). Babies who experience skin-to-skin contact immediately after birth are more self-regulated and have a more attuned relationship with their mothers than those who were swaddled or separated; however, the negative influence of swaddling appears to be mitigated by breastfeeding within the first hours after birth (Bystrova et al., 2009).

\section{Breastfeeding: Contents, Length, and Correlates}

Mammalian milk is species specific for each of the more than 4,000 mammalian species (American Academy of Pediatrics Section on Breastfeeding, 2005). Human milk is of the thin, rather than thick, variety, which is related to frequent ingestion or at least frequent suckling (on average every 20 minutes for infants as recorded by anthropologists; see Hewlett \& Lamb, 2005; Konner \& Worthman, 1980). Human mothers, who provided immunity through the placenta, continue to provide immunity after birth, first with colostrum immediately after birth and thereafter with breast milk. Although infants have gastric enzymes for digesting their mother's colostrum and milk, digestive enzymes for other foods do not develop for several months. Breast milk abounds with infection-fighting agents that foster immune and digestive health in the young child. Specific to the environment in which the mother and infant find themselves, mammalian milk produces antibodies for various infective agents (e.g., Slusser \& Powers, 1997). Nutritional practices consistent with evolved, expected care would further facilitate survival and enhance thriving.

The American Academy of Pediatrics recommends that human breast milk be the gold standard against which alternative infant food should be weighed in terms of its impact on human growth and development. Human breast milk, besides providing a balanced spectrum of macro- and micronutrients, also contains various enzymes, growth factors, hormones, and other 
live, health-protective agents including the five basic immunoglobulins, IgG, IgA, IgM, IgD, and IgE; breast milk fats and cholesterol co-occur with enzymes, such as lipase, that break down fats (for a review, see Goldman, 1993). Most of these elements are not contained in infant formula. For example, breast milk contains the protein adiponectin that affects how the body processes sugars and fatty substances in the blood; higher levels of adiponectin are related to lower levels of disease and obesity (Martin et al., 2006). Only recently have infant formulas started to supplement tryptophan, the precursor of serotonin, which is linked to the sleep-wake cycle and emotional tone; both are involved in many brain functions including reducing depression (Goldman, 1993; Delgado, 2006). Maternal milk is a rich source of unsaturated fatty acids, bioactive nutrients that are essential to early brain development (Yehuda, Rabinovitz, \& Mostofsky, 1999). Not all formulas include DHA (docosahexaenoic acid, an essential omega-3 fatty acid) in presumably optimal proportions, which is important for visual and cognitive development (Hart et al., 2006; Lauritzen, Hansen, Jørgensen, \& Michaelsen, 2001; Michaelsen, Lauritzen, Jørgensen, \& Mortensen, 2003). Breast milk supports the growth of Lactobacillaceae, found 10 times higher in breastfed infants, which inhibits gram-negative bacteria and parasites (Newburg \& Walker, 2007). In comparison to formula, breastfeeding decreases risks in the infant for specific diseases from small to large including infections, diarrhea, meningitis, ear infections, diabetes, and cancer and is protective from disease in general (for a review, see AAP, 2005). Breastfeeding in the environment of evolutionary adaptedness presumably went on for anywhere from 2 to 5 years or longer (average weaning age of 4 years; for a review, see Hrdy, 2009, also for alloparent provisioning practices). These patterns are still evident in aboriginal populations little influenced by outside cultures. Five to 7 years is about the time needed for the immune system to develop adult-level functioning (Parham, 2004). In the United States, only 
$11.3 \%$ of mothers breastfeed exclusively at 6 months (which is recommended), and only $15.7 \%$ are breastfeeding at all at 12 months (Scanlon et al., 2007), although subgroups have different rates (McDowell, Wang, \& Kennedy-Stephenson, 2008). See Sulaiman, Amir, and Liamputtong (this volume) for a review of the challenges to breastfeeding in the modern world. A shorter duration of breastfeeding (less than 6 months) may be a predictor of adverse mental health outcomes throughout the developmental trajectory of childhood and early adolescence (Oddy et al., 2010). The World Health Organization recommends a minimum of 2 years of breastfeeding (the American Academy of Pediatrics recommends a minimum of 1 year).

Patterns of mother-infant interaction differ between breastfeeding and bottle-feeding. The amount of mother's gaze, tactile stimulation, and mutual touch are significantly elevated in breastfeeding compared to formula feeding (Lavelli \& Poli, 1998). In comparison to formula feeding, breastfeeding is linked to improved mental outcomes such as increased IQ—-with longer breastfeeding being better (e.g., Mortensen, Michaelsen, Sanders, \& Reinisch, 2002; although see Kramer et al., 2001). The IQs of the $90 \%$ of children who have a genetic variant in FADS2 appear to be benefited especially by breastfeeding (Caspi et al., 2007). For a meta-analysis of the positive effects of breastfeeding on brain development, see Michaelsen and colleagues (2003). Studies suggest a greater degree and severity of illness among formula-fed infants regardless of background (e.g., Garza, 1987; AAP, 1997). Note, however, that the positive effects of breastfeeding may well be attenuated in this research. After all, studies comparing formula feeding and breastfeeding often evaluate consequences over short time periods such as 3 or 6 months (for a review see Kramer \& Kakuma, 2004). For a more veridical comparison between the experiences of our prehistoric ancestors and modern humans, the comparison group should be children breastfed for at least 2 years if not longer. 


\section{Physical Closeness, Affectionate Touch, and Social Bonding}

The effects of physical affection on optimal functioning in mammals have garnered attention for some time (e.g., Harlow, 1958). For most mammalian offspring, losing contact with a caregiver is distressing. Even short bouts of separation from the mother causes lifelong changes in stress responsivity for infant rats (Levine, 2005). Although when developmentally appropriate, mild and graded brief separations can help the offspring cope with the stress of longer separations later (Katz et al., 2009) but otherwise can have lasting negative effects. Hofer’s $(1987,1994)$ work with rats has shown that multiple systems are regulated by the presence of the mother and quickly become dysregulated when she is physically absent. Even in species less social than ours, physical separation activates painful emotions (Ladd, Owens, \& Nemeroff, 1996; Panksepp, 2003; Sanchez et al., 2001) and influences the dynamics of various emotionregulating hormones and neuropeptides (Cirulli, Francia, Berry, Aloe, Alleva, \& Suomi 2009). Monkeys isolated from adults when young spend their lives with deficits of 5-HIAA, the main metabolite of serotonin, resulting from reduced serotonin production and utilization, which have been linked to impulsive violent and antisocial behavior in mammals (Kalin, 1999; Suomi, 2006). Excessive separation distress during early development sets up the nervous system for depressive disorders later in life, through well-established affective systems of the brain (see Panksepp \& Watt, 2011, and Watt \& Panksepp, 2009, for overviews).

Physical touch and affection have long-lasting general health effects as well (see Field, this volume). Meaney and colleagues have documented differences in gene expression within the brain-body pituitary-adrenal stress axis, based on the extent of maternal touch soon after birth (Meaney, this volume; Szyf, Weaver, \& Meaney, 2007; Weaver et al., 2002). Examining only one of dozens, perhaps even thousands (as observed in unpublished work on primates by Steve 
Suomi and the aforementioned investigators), of genes affected, Meaney and colleagues found that rats with high-touch (high-licking) mothers in the first 10 days of life had elevated gene expressions for glucocorticoid receptor proteins. Glucocorticoid hormones produced in all mammals in response to stress need to be well regulated to prevent excessive stress, hippocampal dysfunction, and eventual depression (McEwen, 2007). Rats with diminished maternal touch had weaker stress axis regulation, resulting in more anxiety and lifelong heightened responses to stress across a diverse range of brain and behavioral measures (Champagne \& Meaney, 2001). Moreover, these effects spiraled across generations. A low-nurturing mother bred low-nurturing daughters, epigenetically further compounding the effects of poor care on brain system development over generations (Weaver et al., 2002). Cross-foster studies show that the effect is environmental and not genetic (Francis, Diorio, Liu, \& Meaney, 1999). Meaney, Szyf, and colleagues have now demonstrated the same epigenetic mechanism occurring in the brains of human adults abused as children who subsequently committed suicide (McGowan et al., 2009).

Animal studies on the critical importance of early tactile experience in mammalian development are paralleled by human studies on the essential role of maternal "affective touch" on infant development in the first year of life (Ferber, Feldman, \& Makhoul, 2008; Jean, Stack, \& Fogel, 2009). The infant and mother utilize "interpersonal touch" as an initial communication system (Gallace \& Spence, 2010), especially for the relay and regulation of emotional information (Hertenstein, 2002; Hertenstein \& Campos, 2001). Echoing animal research, human studies indicate that a lack of interpersonal touch in mother-infant interactions has an enduring negative effect on psychological, especially emotional, development (e.g., Moszkowski et al., 2009). 
In the ancestral context, represented by the EEA, and as is normal for our ape cousins, babies and young children were presumably kept physically in contact with their mothers and others all the time, day and night. McKenna and colleagues (1994) have documented hidden regulators during human mother-child cosleeping, including facilitation of regular feeding/suckling (Ball \& Klingaman, 2007; Ball \& Russell, this volume; Buswell \& Spatz, 2007; McKenna \& Gettler, this volume; Thoman, 2006). Skin-to-skin contact promotes healthy sleep cycles and adaptive behavioral arousals and exploratory activities (Feldman, Weller, Sirota, \& Eidelman, 2002; McKenna, Ball, \& Gettler, 2007). Early experiences with physical touch influence brain structures and wiring, facilitating secure attachments, which in turn promote adaptive social and cognitive functioning in adulthood (for a review, see Cushing \& Kramer, 2005). Early social loss and insecure attachment are linked to a predisposition for depression and other mental health problems (e.g., Beatson \& Taryan, 2003; Watt \& Panksepp, 2009). These findings must be considered in light of the fact that only about 13\% of US infants regularly sleep in a bed near caregivers (National Institute of Child Health and Human Development, Early Child Care Research Network, 2003).

\section{Prompt (Caring) Response}

After 9 months of gestational synchrony, human mothers and neonates under natural conditions typically move into an interactional synchrony of sound and movement within the first hours after birth (e.g., Condon \& Sander, 1974; Papousek \& Papousek, 1992). Some call this rightbrain affect regulation (Schore, 1994, 2003) or “limbic regulation” (Lewis, Amini, \& Lannon, 2000), in which caregivers act as external regulators of psychological and biological development (Hofer, 1994; Schore, 2001b). This positive emotional entrainment is of clear importance in long-term development after birth (for reviews, see Reddy, 2008; Tronick, 2007). 
According to the mutual regulation model, the infant is viewed as a subsystem, with the caregiver as the other subsystem, within a "larger dyadic regulatory system” (Tronick, 2007, p. 9) that is in a constant dance of match and mismatch of coordinating intersubjectivity (Reddy, 2008). The infant's experience of repairing communication mismatches with coping strategies (also dependent on mother responsiveness) is believed to lead to a sense of mastery and a positive affective core, whereas opposite outcomes occur for an infant who unsuccessfully uses coping strategies in trying to repair communication mismatches. Consonant with this model, Schore (1994, 2000, this volume) describes the cocreation of an attachment bond of socialemotional communication and interactive regulation between the infant and the sensitive primary caregiver in the first 2 years of life. Optimal human development is thus rooted in social synchrony with others (Reddy, 2008; Schore, 1994; Trevarthen, 2005). Moreover, collective intelligence of human groups is largely based on social sensitivity (Woolley, Chabris, Pentland, Hashmim, \& Malone, 2010).

In early life, the right brain is forming its emotional circuitry and structures in collaboration with caregivers (for reviews, see Schore, 1994, 2001b). Responsive caregivers, in mutual coregulation, shape the infant brain for self-regulation within and across multiple sensory systems (e.g., respiratory, hormonal), influencing multiple levels of functioning (Hofer, 1994) and establishing emotional patterns that promote confidence and mental health. The early developing right brain, which is shaped by the attachment relationship and dominant for the processing of bodily based emotional information, is deeply connected to the autonomic nervous system (Schore, 2005), providing a solid grounding for an emotionally well-integrated personality (McGilchrist, 2009; Nadel \& Muir, 2005). Porges’s polyvagal theory details how early attachment bonding experiences program the sympathetic and parasympathetic branches of 
the infant's developing autonomic nervous system, thereby shaping later social and emotional reactivity (Carter \& Porges, this volume; Porges, 2007). Indeed, responsive care with coregulated communication patterns is related to good parasympathetic vagal tone, which is critical for wellfunctioning digestive, cardiac, respiratory, and immune as well as emotional systems (e.g., Donzella, Gunnar, Krueger, \& Alwin, 2000; Propper et al., 2008; Stam, Akkermans, \& Wiegant, 1997). Nonresponsive parenting leads to poor vagal tone (e.g., Calkins, Smith, Gill, \& Johnson, 1998; Porter, 2003). Other systems are also affected negatively. For example, having a depressed mother (whose nurturing responses are limited) alters the functioning of the hypothalamicpituitary-adrenal axis (HPA; e.g., Beatson \& Taryan, 2003; see Dawson, Ashman, \& Carver, 2000, for a review).

Unfortunately, a common cultural misperception, arising partly from the behaviorist tradition, is that letting babies cry themselves to sleep represents adequate, or even appropriate, parenting (Gethin \& MacGregor, 2009). When babies are left to cry, with no parental attempt at timely comforting, their brains are flooded with high levels of potentially neurotoxic stress hormones such as cortisol (Blunt Bugental, Martorell, \& Barraza, 2003; Gunnar \& Donzella, 2002). Brain opioids, which promote feelings of well-being, diminish during human sadness (Zubieta et al., 2003), and psychic pain circuits are aroused (Eisenberger, Lieberman, \& Williams, 2003; Panksepp, 2003). Over time, if these experiences are regular and extended, brain stress response systems can be wired permanently for oversensitivity and overreactivity (Anisman, Zaharia, Meaney, \& Merali, 1998), leading to predispositions for clinical depression and anxiety (Barbas, Saha, Rempel-Clower, \& Ghashghaei, 2003; de Kloet, Sibug, Helmerhorst, \& Schmidt, 2005; see Watt \& Panksepp, 2009, for a review), poor mental and physical health outcomes, and accelerated aging and mortality (for a review, Preston \& de Waal, 2002). 
Consistent or unrelieved distress during sensitive periods in early life reduces the expression of $\gamma$-aminobutyric acid (GABA) genes, leading to anxiety and depression disorders as well as increased use of alcohol for stress relief (Caldji, Francis, Sharma, Plotsky, \& Meaney, 2000; Hsu et al., 2003). When emotional dysregulation becomes chronic, it forms the foundation for further psychopathologies (Cole, Michel, \& Teti, 1994; Panksepp \& Watt, 2011), especially depression. Infant emotional dysregulation is related to subsequent mental illness, including a propensity for violence (Davidson, Putnam, \& Larson, 2000). Stress that leads to insecure attachment disrupts emotional functioning, compromises social abilities, and can promote a permanent emotional bias toward anxious self-preservation (Henry \& Wang, 1998; also see Schore, 2009, for a review).

Warm, responsive caregiving, as extensively studied (but variably defined; see Richman, Miller, \& LeVine, 1992), is shown to have multiple positive effects (Fleming, Mileva-Seitz, \& Afonso, this volume). Children raised with abundant care develop systems that respond well to endogenous opioids and oxytocin, leading to better stress regulation (e.g., Fleming, O’Day, \& Kraemer, 1999; Heim \& Nemeroff, 2001; Liu et al., 1997; Uvnas-Moberg, 1997). Responsive parenting helps children learn to regulate arousal systems on their own (Haley \& Stansbury, 2003) and is linked to heightened moral functioning, including stronger early conscience development (Kochanska, 2002). Well-established vagal tone in adults is correlated with compassion and openheartedness toward others from different backgrounds (summarized by Keltner, 2009). Similarly, children with high vagal tone are more cooperative and giving (for a review, see Eisenberg \& Eggum, 2008). And when combined with increased activity in positive affective systems of the brain, high vagal tone promotes human happiness (Sheldon, Kashdan, \& 
Steger, 2011) as opposed to sustained psychological pain (MacDonald \& Jensen-Campbell, 2011).

\section{Multiple Allomothers}

Family life was established on cooperation (Roughgarden \& Song, in press). In the ancestral context, with humans living in small tribal, extended family groups, mothers were probably often assisted by many other adults (e.g., father, grandparents) in caring for infants and children, suggesting that children had multiple attachment relationships. Such "cooperative breeding” is corroborated by contemporary observational studies of similar groups (see review by Hrdy, 2009). For example, youngsters require feeding long after weaning, an activity the mother necessarily shares with other adults in documented hunter-gatherer communities until the child is able to help sufficiently to provision the self and others (see Fuentes, in press). Historically, the built-in social safety net for mothers surely increased the chances of the child's survival and decreased the stress burden on the mother. Supportive social contact is known to be a positive influence during birthing and postnatal mother-child communication (Klaus \& Kennel, 1976), and in fact, three attentive adults (parents and/or alloparents) appear to be optimal for children to thrive (Sagi et al., 1995; van Ijzendoorn, Sagi, \& Lambermon, 1992).

In contrast to our ancestral context, modern life includes several caregiving arrangements that most likely compromise optimal child development. Single parenthood, for instance, can be detrimental to the well-being of the child (Amato, 2007), likely owing to overall decreased social support. Another current practice in the United States is that most children are cared for by nonkin caregivers, who may be less attuned to the needs of individual children than family members might be (Belsky, 2001), and where less than optimal care is often provided due to lack of resources (Peisner-Feinberg, Bernier, Bryant, \& Maxwell, 2000). The more time that children 
spend in any nonmaternal childcare situations across the first 4.5 years of life, the more likely they are to exhibit externalizing problems and conflict with adults at age 4.5 and in kindergarten (National Institute of Child Health and Human Development, Early Child Care Research Network, 2003; although the rare high-quality care may mitigate these effects). In comparison to children at home (a proxy for care that is closer to that provided in the ancestral context), cortisol readings are higher for children in daycare, especially for those under 3 years of age (Vermeer \& van Ijzendoorn, 2006), and increase rather than decrease throughout the day (Dettling, Gunnar, \& Donzella, 1999). The expulsion rate of prekindergarten children (Gilliam, 2005) and the number of children under age 5 with psychosocial problems (Powell et al., 2003) or on psychotropic medications have increased dramatically in recent years (Zito et al., 2000), and although these trends have not yet been causally connected to deficient childcare, they do suggest that early caregiving is problematic in some way. Poor-quality daycare settings are often not able to cope with children's needs, particularly if they exhibit psychosocial problems or special needs.

Play

Mammalian childhoods, especially among primates, are characterized by playful interactions. The natural play of mammals has only recently been ethologically characterized for humans (Scott \& Panksepp, 2003) and put under close scientific scrutiny in animal models (Panksepp, Siviy, \& Normansell, 1984; Pellis \& Pellis, 2009; Siviy \& Panksepp, 2011; Spinka, Newberry, \& Bekoff, 2001; Vanderschuren, Niesink, \& Van Ree, 1997). Gray (2009; this volume), and Pellegrini (this volume) describe the evolved usefulness of play. Play is now known to promote affectively beneficial gene expression profiles (Burgdorf, Kroes, Beinfeld, Panksepp, \& Moskal, 2010), brain development (Gordon, Kollack-Walker, Akil, \& Panksepp, 2002; Gordon, Burke, 
Akil, Watson, \& Panksepp, 2003; Panksepp, 2007; van den Berg et al., 1999), and emotion regulation development (Panksepp et al., 2003; van den Berg et al., 1999). Mammals who are deficient in play have difficulty regulating aggressive urges (Potegal \& Einon, 1989). Those with little play experience early in life have altered social, sexual, and conflict interactions with peers (van den Berg et al., 1999). Insufficient play may promote behavioral disorders such as attention deficit/hyperactivity disorder (Panksepp, 2007), diminished academic achievement (Barros, Silver, \& Stein, 2009), and aggression (Flanders \& Herman, this volume). Unfortunately, physical play in kindergarten is disappearing (Miller \& Almon, 2009); moreover, educators often have difficulty distinguishing play from aggression and are commonly uncertain about how to manage play urges in young children (Tannock, 2008).

\section{What Happens to Mammals Who Do Not Receive What They Need?}

Mammalian brains are experience expectant (Greenough \& Black, 1992), with age-related regulating sets of experiences and environmental supports promoting brain construction and wiring (e.g., Cushing \& Kramer, 2005). Caregiving consistent with evolved, expected care could be conceptualized as a set of experiences anticipated by the human mammalian brain that foster empathy and sociality (Narvaez \& Gleason, this volume; Nelson, this volume). Of course, all organisms, including humans, adapt to whatever life-supportive environments they encounter. Mammals, including young humans, adapt to emotionally deficient environments by relying on the more primitive survival modes of their brains, often becoming aggressive, depressive, and/or antisocial (Henry \& Wang, 1998; Lewis et al., 2000; Teicher, 2002). Perhaps, then, the increasing incidence of emotionally disorganized children is a form of adaptation that is an “adaptive maladaptation," from a mental health perspective, formed in response to "toxic social environments” (Garbarino, 1995) — environments deficient in the kinds of inclusive social 
supports our ancestors received. That is, such maladaptations were not part of the evolved adaptive apparatus but reflect a pathological outcome of emotional stressors in human infants reared in socially deficient environments without adequate social supports, resulting in deficient limbic and neocortical development. Schore (1997, 2002), for example, offers interdisciplinary evidence that indicates that relational attachment trauma alters the developmental trajectory of the right brain and thereby imprints a predisposition to later forming psychiatric disorders, including personality disorders.

Under the ancestral conditions (small-band hunter-gatherers; Fry, 2006), individuals would have developed a stronger disposition to cooperate and to exhibit "strong reciprocity" (Gintis, Bowles, Boyd, \& Fehr, 2009, p. 8). Oppositional, aggressive, and/or dangerous individuals would not have earned the trust of the community and likely would have died at younger ages in our ancestral context than cooperative individuals. Poor cooperators may more readily survive today because of the sufficient calories and attention provided through the cultural safety nets of modern societies. Nonetheless, through the neglect of children's various primary social-emotional needs, our society may be starting to normalize abnormality.

\section{Alternative views}

Hrdy (1999) has suggested that children reared under adverse conditions (e.g., with stressed parents) may develop personalities (e.g., anxious) that are better prepared for subsisting in a challenging environment. For example, when children are presented with manageable, graded emotional challenges, they can become more resilient (e.g., Katz et al., 2009). However, relational neglect and/or attachment trauma presents the infant not with graded but with highly stressful, undernourishing, and thereby overwhelming experiences. In fact, severe attachment stressors decrease adaptive abilities to respond emotionally, think efficiently, and relate well to 
others (Lanius et al., 2010). As a result, these children are truly not "prepared” for the social environment they face in everyday life. What is more, trauma may not need to be severe to have detrimental effects. Undercare, in terms of our ancestral practices, may also lead to suboptimal functioning (see Narvaez \& Gleason, this volume). Surely the range of undercare in ancestral environments was much narrower and limited for our ancestors because children lived within a village of support. They experienced much more physiological stress but many fewer social stresses than childrearing environments today. Social stress has much greater ill effects on child physical and mental well-being than physiological stress (see Konner, 2010, for a review).

Others suggest that humans are demonstrating how adaptive and resilient they are despite the huge spectrum of stressful childhood experiences expressly because they survive in the face of daunting challenges (e.g., Belsky, Steinberg, \& Draper, 1991). This perspective, however, ignores the quality of life, and even its length, as important variables in understanding adaptation. Suomi and colleagues (Howell et al., 2007), for example, found that male rhesus monkeys with low central serotonin levels early in life, a genetic phenotype that can be modulated environmentally, demonstrate high levels of violence and often experienced premature death; those that survive to adulthood (10 years later) achieve high rank, but it is not clear how functional they are otherwise (D’Souza \& Craig, 2008; Rutter, 2008; Suomi, 2006; Uher \& McGuffin, 2008). After all, dominant human males typically do not out-reproduce less dominant males (Lansing et al., 2008).

The wide range of personalities found today (many "pathological”) were likely not found in ancestral contexts. Rearing practices that reduced childhood crying were adaptive (Trevathan, 2011); children were probably more "indulged” (Konner, 2005), resulting in apparently conciliatory personalities (Fry, 2006), not the wide range of antisocial personalities that are 
documented currently. Support for this argument comes from anthropological reports (e.g., Thomas, 1959; Turnbull, 1961) and a review by Prescott (1996), who compared violent and peaceful societies from Textor's (1967) analyses of 400 societies and found that peaceful societies were more physically nurturing (touch, holding, affection) than violent societies. The evolved, expected care we describe appear to lead to not only more cooperative personalities but also more peaceful cultures (Fry, 2006; Narvaez \& Gleason, this volume).

Perhaps because of a long evolutionary history with relatively egalitarian social structures in ancestral environments (Binmore, 1998) and a deep sense of fairness exhibited among primates (e.g., Brosnan, 2006; Brosnan \& de Waal, 2003; de Waal, 2009; now extended to various species), humanity’s troubled history during the recent “modern” era of inegalitarianism (the last 10,000 years or so) may be linked to the more powerful members of society exhausting societal resources from a status race to the top (Diamond, 2005. One reading of modern history is that the human global trajectory is less than optimal (Millennium Ecosystem Assessment, 2005) and seems to be following the same self-destructive pattern as societies that collapsed in the past (Diamond, 2005-only with worldwide ramifications.

A latent variable that underlies one's reaction to the state of children today is one's subjective view of human nature. If one believes that humans are naturally violent and individualistic, then one is not surprised that so much violence, aggression, and alienation pervade society. However, if one believes that humans are typically nonviolent but prosocial, one is more likely to view aggression and alienation as indicative of an unbalanced state of affairs that can be remedied. Clearly, we take the latter position.

\section{Conclusion}


Current US societal practices and accepted childrearing outcomes do not adequately consider the original adaptive conditions of our ancestry and the prosocial emotional dynamics that helped human ancestors to thrive. Despite the growing evidence for the negative effects of particular early experiences, especially as moderated by emotionally sensitive childrearing practices on the developing brain, scientific research, theory, and policy recommendations do not yet match up with emerging findings. At the same time, we do not wish to romanticize a human ancestral past that cannot be reconstructed precisely, but to provide a plausible thesis, supported by crossspecies data, that includes sensitive studies of the emotional-cognitive capacities of our evolutionary ancestors, as gleaned from studies of our closest evolutionary kin, the other great apes (de Waal, 2009). The primordial emotional infrastructure of mammalian brains (Panksepp, 1998, 2005; Panksepp \& Biven, 2011) clearly coevolved with a particular co-constructing environment such as is described here. In order for science to play an effective role in helping to reverse current negative trends in well-being, we need to foster a widespread understanding of the types of psychobiological needs that humans possess as a result of their evolutionary nature. Paying attention to the converging evidence about optimal early care is a place to start. This volume is a contribution to that effort.

\section{Acknowledgments}

The first author would like to thank the Spencer Foundation and the University of Notre Dame for their support during the writing of this chapter. The second author thanks the Hope for Depression Research Foundation for support. The fourth author thanks the Brachman-Hoffman Small Grants for support.

References 
Amato, P. R. (2007, July). The impact of family formation change on the cognitive, social, and emotional well-being of the next generation. The Future of Children, 15(2), 75-96.

American Academy of Child and Adolescent Psychiatry. (2011). Campaign for America's kids. Retrieved January 19, 2011, from http://www.campaignforamericaskids.org/

American Academy of Pediatrics Section on Breastfeeding. (2005). Breastfeeding and the use of human milk. Pediatrics, 115(2), 496-506.

American Academy of Pediatrics Work Group on Breastfeeding. (1997). Breastfeeding and the use of human milk policy statement. Pediatrics, 100(6), 1035-1039.

Anders, T. F., \& Chalemian, R. J. (1974). The effects of circumcision on sleep-wake states in human neonates. Psychosomatic Medicine, 36(2), 174-179.

Ang, Jr., E. S. B. C, Gluncic, V., Duque, A., Schafer, M. E., \& Rakic, P. (2006). Prenatal exposure to ultrasound waves impacts neuronal migration in mice. PNAS, 103(34), 12903-12910.

Anisman, H., Zaharia, M. D., Meaney, M. J., \& Merali, Z. (1998). Do early-life events permanently alter behavioral and hormonal responses to stressors? International Journal of Developmental Neuroscience, 16(3-4), 149-164.

Ball, H. L., \& Klingaman, K. P. (2007). Breastfeeding and mother-infant sleep proximity: Implications for infant care. In W. Trevathan, E. O. Smith, \& J. J. McKenna (Eds.), Evolutionary medicine and health: New perspectives (pp. 226-241). New York, NY: Oxford University Press.

Barbas, H., Saha, S., Rempel-Clower, N., \& Ghashghaei, T. (2003). Serial pathways from primate prefrontal cortex to autonomic areas may influence emotional expression. Neuroscience, 4(1), 25. 
Barros, R. M., Silver, E. J., \& Stein, R. E. K. (2009). School recess and group classroom behavior. Pediatrics, 123(2), 431-436.

Beatson, J., \& Taryan, S. (2003). Predisposition to depression: The role of attachment. The Australian and New Zealand Journal of Psychiatry, 37(2), 219-225.

Belsky, J. (2001). Developmental risks (still) associated with early child care. Journal of Child Psychology and Psychiatry and Allied Disciplines, 42(7), 845-859.

Belsky, J., Steinberg, L., \& Draper, P. (1991). Childhood experience, interpersonal development and reproductive strategy. Child Development, 62, 647-670.

Binmore, K. G. (1998). Game theory and the social contract II. Just playing. Cambridge, MA: MIT.

Blunt Bugental, D., Martorell, G. A., \& Barraza, V. (2003). The hormonal costs of subtle forms of infant maltreatment. Hormones and Behaviour, 43(1), 237-244.

Bowlby, J. (1951). Maternal care and mental health. New York, NY: Schocken.

Bowlby, J. (1980). Attachment and loss: Vol 3. Loss: Sadness and depression. New York, NY: Basic Books.

Bowlby, J. (1988). A secure base: Parent-child attachment and healthy human development. New York, NY: Basic Books.

Bronfenbrenner, U. (1979). The ecology of human development. Cambridge, MA: Harvard University Press.

Brosnan, S. F. (2006). Nonhuman species’ reactions to inequity and their implications for fairness. Social Justice Research, 19(2), 153-185.

Brosnan, S. F., \& de Waal, F. B. (2003). Monkeys reject unequal pay. Nature, 425(6955), 297299. 
Burgdorf, J., Kroes, R. A., Beinfeld, M. C., Panksepp, J., \& Moskal, J. R. (2010). Uncovering the molecular basis of positive affect using rough-and-tumble play in rats: A role for insulinlike growth factor I. Neuroscience, 168, 769-777.

Buswell, S. D., \& Spatz, D. L. (2007). Parent-infant co-sleeping and its relationship to breastfeeding. Journal of Pediatric Health Care, 21, 22-28.

Bystrova, K., Ivanova, V., Edhborg, M., Matthiesen, A. S., Ransjö-Arvidson, A. B., Mukhamedrakhimov, R., . . Widström, A. M. (2009). Early contact versus separation: Effects on mother-infant interaction one year later. Birth, 36(2), 97-109.

Cacioppo, J. T., \& Berntson, G. G. (1992). Social psychological contributions to the decade of the brain: Doctrine of multilevel analysis. American Psychologist, 47, 1019-1028.

Caldji, C., Francis, D., Sharma, S., Plotsky, P. M., \& Meaney, M. J. (2000). The effects of early rearing environment on the development of GABAA and central benzodiazepine receptor levels and novelty-induced fearfulness in the rat. Neuropsychopharmacology, March, 219-229.

Calkins, S. D., Smith, C. L., Gill, K. L., \& Johnson, M. C. (1998). Maternal interactive style across contexts: Relations to emotional, behavioral and physiological regulation during toddlerhood. Social Development, 7(3), 350-369.

Carter, C. S. (1998). Neuroendocrine perspectives on social attachment and love. Psychoneuroendocrinology, 23(8), 779-818.

Carter, C. S. (2003). Developmental consequences of oxytocin. Physiology and Behavior, 79(3), 383-397. 
Caspi, A., Williams, B., Kim-Cohen, J., Craig, I. W., Milne, B. J., Poulton, R., . . Moffitt, T. E. (2007). Moderation of breastfeeding effects on the IQ by genetic variation in fatty acid metabolism. PNAS, 104(47), 18860-18865.

Champagne, F., \& Meaney, M. J. (2001). Like mother, like daughter: Evidence for non-genomic transmission of parental behavior and stress responsivity. Progress in Brain Research, 133, 287-302.

Cirulli, F., Berry, A., \& Alleva, E. (2002). Early disruption of the mother-infant relationship: Effects on brain plasticity and implications for psychopathology. Neuroscience and Biobehavioral Reviews, 272, 73-82.

Cirulli, F., Francia, N., Berry, A., Aloe, L., Alleva, E., \& Suomi S. J. (2009). Early life stress as a risk factor for mental health: Role of neurotrophins from rodents to non-human primates. Neuroscience and Biobehavioral Reviews0, 573-585.

Cole, P. M., Michel, M. K., \& Teti, L. O. (1994). The development of emotion regulation and dysregulation: A clinical perspective. Monographs of the Society for Research in Child Development, 59(2-3), 73-100.

Commission on Children at Risk. (2003). Hardwired to connect: The new scientific case for authoritative communities. New York, NY: Institute for American Values:

Condon, W. S., \& Sander, L. W. (1974). Neonate movement is synchronized with adult speech: Interactional participation and language acquisition. Science, 183, 99-101.

Cushing, B. S., \& Kramer, K. M. (2005). Mechanisms underlying epigenetic effects of early social experience: The role of neuropeptides and steroids. Neuroscience and Biobehavioral Reviews, 29(7), 1089-1105. 
Davidson, R. J., Putnam, K. M., \& Larson, C. L. (2000) Dysfunction in the neural circuitry of emotion regulation—a possible prelude to violence. Science, 289(5479), 591-594.

Davis, E. P., \& Sandman, C. A. (2010). The timing of prenatal exposure to maternal cortisol and psychosocial stress is associated with human infant cognitive development. Child Development, 81(1), 131-148.

Dawson, G., Ashman, S. B., \& Carver, L. J. (2000). The role of early experience in shaping behavioral and brain development and its implications for social policy. Development and Psychopathology, 12, 695-712.

De Kloet, E. R., Sibug, R. M., Helmerhorst, F. M., \& Schmidt, M. (2005). Stress, genes and the mechanism of programming the brain for later life. Neuroscience and Biobehavioral Reviews, 29(2), 271-281.

De Waal, F. (2009). In S. Macedo \& J. Ober (Eds.), Primates and philosophers: How morality evolved. Princeton, NJ: Princeton University Press.

Delgado, P. L. (2006). Monoamine depletion studies: Implications for antidepressant discontinuation syndrome. Journal of Clinical Psychiatry, 67(Suppl 4), 22-26.

Dettling, A. C., Gunnar, M. R., \& Donzella, B. (1999). Cortisol levels of young children in fullday childcare centers: Relations with age and temperament. Psychoneuroendocrinology, 24(5), 519-536.

Devitt, N. (1977). The transition from home to hospital birth in the United States, 1930-1960. Birth, 4, 47-58.

Diamond, J. (2005). Collapse: How societies choose to fail or survive. New York, NY: Viking. Doidge, N. (2007). The brain that changes itself. New York, NY: Viking. 
Donzella, B., Gunnar, M. R., Krueger, W. K., \& Alwin, J. (2000). Cortisol and vagal tone responses to competitive challenge in preschoolers: Associations with temperament. Development Psychobiology, 37(4), 209-220.

D’Souza, U. M., \& Craig, I. W. (2008). Functional genetic polymorphisms in serotonin and dopamine gene systems and their significance in behavioural disorders. Progress in Brain Research, 172, 73-98.

Eccles, J., \& Grootman, J. A. (2002). Community programs to promote youth development. Washington, DC: Committee on Community-Level Programs for Youth. Board on Children, Youth, and Families, Commission on Behavioral and Social Sciences Education, National Research Council and Institute of Medicine.

Eisenberg, N., \& Eggum, N. D. (2008). Empathic responding: Sympathy and personal distress. In B. Sullivan, M. Snyder, \& J. Sullivan (Eds.), Cooperation: The political psychology of effective human interaction (pp. 71-83). Malden, MA: Blackwell Publishing.

Eisenberger, N. I., Lieberman, M. D., \& Williams, K. D. (2003). Does rejection hurt? An FMRI study of social exclusion. Science, 302, 290-292.

Emde, R. N., Harmon, R. J., Metcal, D., Koenig, K. L., \& Wagonfeld, S. (1971). Stress and neonatal sleep. Psychosomatic Medicine, 33, 491-497. 47.

Feldman, R., Weller, A., Sirota, L., \& Eidelman, A. I. (2002). Skin-to-skin contact (kangaroo care) promotes self-regulation in premature infants: Sleep-wake cyclicity, arousal modulation, and sustained exploration. Developmental Psychology, 38, 194-207.

Felitti, V. J., \& Anda, R. F. (2005). The Adverse Childhood Experiences (ACE) study. Atlanta, GA: Centers for Disease Control and Prevention and Kaiser Permanente. 
Ferber, S. G., Feldman, R., \& Makhoul, I. R. (2008). The development of maternal touch across the first year of life. Early Human Development, 84, 363-370.

Fleming, A. S., O’Day, D. H., \& Kraemer, G. W. (1999). Neurobiology of mother infant interactions: Experience and central nervous system plasticity across development and generations. Neuroscience and Biobehavioral Reviews, 3(5), 673-685.

Fraga, M. F., Ballestar, E., Paz, M. F., Ropero, S. Setien, F., Ballestar, M. L., . . . Esteller, M. (2005). Epigenetic differences arise during the lifetime of monozygotic twins. Proceedings of the National Academy of Sciences of the United States of America, 102(30), 10604-10609.

Francis, D., Diorio, J., Liu, D., \& Meaney, M. J. (1999). Nongenomic transmission across generations of maternal behavior and stress responses in the rat. Science, 286, 11551158.

Fry, D. P. (2006). The human potential for peace: An anthropological challenge to assumptions about war and violence. New York, NY: Oxford University Press.

Fry, D. P. (2009). Beyond war: The human potential for peace. New York, NY: Oxford University Press.

Fuentes, A. (in press). Preliminary steps towards addressing the role of non-adult individuals in human evolution. In D. Narvaez, K. Valentino, A. Fuentes, J. McKenna, \& P. Gray, Ancestral Landscapes in Human Evolution: Culture, Childrearing and Social Wellbeing. New York: Oxford University Press.

Gallace, A., \& Spence, C. (2010). The science of interpersonal touch: An overview. Neuroscience and Biobehavioral Reviews, 34, 246-259. 
Garbarino, J. (1995). Raising children in a socially toxic environment. San Francisco, CA: Jossey-Bass.

Garza, C. (1987). Special properties of human milk. Clinics of Perinatology, 14, 11-32.

Gethin, A., \& Macgregor, B. (2009). Helping baby sleep: The science and practice of gentle bedtime parenting. Berkeley, CA: Ten Speed Press.

Gilliam, W. S. (2005). Prekindergarteners left behind: Expulsion rates in state prekindergarten systems. New Haven, CT: Yale University Child Study Center.

Gintis, H., Bowles, S., Boyd, R., \& Fehr, E. (2009). Moral sentiments and material interests: Origins, evidence, and consequences. In H. Gintis, S. Bowles, R. Boyd, \& E. Fehr (Eds.), Moral sentiments and materials interests: The foundations of cooperation in economic life (pp. 3-40). Cambridge, MA: MIT Press.

Goldman, A. S. (1993). The immune system of human milk: Antimicrobial anti-inflammatory and immunomodulating properties. Pediatric Infectious Disease Journal, 12(8), 664-671.

Goldman, A. S., Goldblum, R. M., Garza, C., Nichols, B. L., \& O’Brien Smith, E. (1983). Immunologic components in human milk during weaning. Acta Paediatrica Scandinavica, 72(1), 133-134.

Gordon, N. S., Kollack-Walker, S., Akil, H., \& Panksepp, J. (2002). Expression of c-fos gene activation during rough and tumble play in juvenile rats. Brain Research Bulletin, 57(5), 651-659.

Gordon, N. S., Burke, S., Akil, H., Watson, S. J., \& Panksepp, J. (2003). Socially-induced brain 'fertilization': play promotes brain derived neurotrophic factor transcription in the amygdala and dorsolateral frontal cortex in juvenile rats. Neuroscience Letters, 341(1), $17-20$. 
Greenough, W., \& Black, J. (1992). Induction of brain structure by experience: Substrate for cognitive development. In M. R. Gunnar \& C. A. Nelson (Eds.), Minnesota symposia on child psychology 24: Developmental behavioral neuroscience (pp. 155-200). Hillsdale, NJ: Lawrence Erlbaum.

Gunnar, M. R., \& Donzella, B. (2002). Social regulation of the cortisol levels in early human development. Psychoneuroendocrinology, 27(1-2), 199-220.

Haley, D. W., \& Stansbury, K. (2003). Infant stress and parent responsiveness: Regulation of physiology and behavior during still-face and reunion. Child Development, 74, 15231535.

Hamilton, B. E., Martin, J. A., \& Ventura, S. J. (2009). Births: Preliminary data for 2007. National Vital Statistics Reports, 57(12), 2-23.

Hardwired to Connect. (2003). The new scientific case for authoritative communities. New York, NY: Institute for American Values.

Harlow, H. (1958). The nature of love. American Psychologist, 13, 673-685.

Hart, S., Boylan, L. M. Carroll, S. R., Musick, Y. A., Kuratko, C., Border, B. G., \& Lampe, R. L. (2006). Newborn behavior differs with docosahexaenoic acid (DHA) levels in breast milk. Journal of Pediatric Psychology, 31, 221-226.

Hartmann, H. (1939). Ego psychology and the problem of adaptation. New York, NY: International University Press.

Heckman, J. (2008). Schools, skills and synapses. IZA DP No. 3515. Bonn, Germany: Institute for the Study of Labor. 
Heim, C., \& Nemeroff, C. B. (2001). The role of childhood trauma in the neurobiology of mood and anxiety disorders: Preclinical and clinical studies. Biological Psychiatry, 49(12), 1023-1039.

Henry, J. P., \& Wang, S. (1998). Effects of early stress on adult affiliative behavior. Psychoneuroendocrinology, 23(8), 863-875.

Hertenstein, M. J. (2002). Touch: Its communicative functions in infancy. Human Development, 45, 70-94.

Hertenstein, M. J., \& Campos, J. J. (2001). Emotion regulation via maternal touch. Infancy, 2, 549-566.

Hewlett, B. S., \& Lamb, M. E. (2005). Hunter-gatherer childhoods: Evolutionary, developmental and cultural perspectives. New Brunswick, NJ: Aldine.

Hofer, M. A. (1987). Early social relationships as regulators of infant physiology and behavior. Child Development, 58(3), 633-647.

Hofer, M. A. (1994). Hidden regulators in attachment, separation, and loss. In N. A. Fox (Ed.), The Development of Emotion regulation: Behavioral and biological considerations. Monographs of the Society for Research in Child Development, 59 (pp. 192-207). Chicago: University of Chicago Press.

Howell, S., Westergaard, G. C., Hoos, B., Chavanne, T. J., Schoaf, S. E., Cleveland, A., .. . Higley, J. D. (2007). Serotonergic influences on life-history outcomes in free-ranging male rhesus macaques. American Journal of Primatology, 69, 851-865.

Hrdy, S. (1999). Mother Nature: Maternal Instincts and How They Shape the Human Species. New York: Ballantine. 
Hrdy, S. (2009). Mothers and others: The evolutionary origins of mutual understanding. Cambridge, MA: Belknap Press.

Hsu, F. C., Zhang, G. J., Raol, Y. S., Valentino, R. J., Coulter, D. A., \& Brooks-Kayal, A. R. (2003). Repeated neonatal handling with maternal separation permanently alters hippocampal GABAA receptors and behavioural stress responses. Proceedings of the National Academy of Sciences of the United States of America, 155, 12213-12218.

Insel, T. J. (1997). A neurobiological basis of social attachment. American Journal of Psychiatry, 154(6), 726-735.

Insel, T. R., Gingrich, B. S., \& Young, L. J. (2001). Oxytocin: Who needs it? Progress in Brain Research, 133, 59-66.

Jean, A. D. L., Stack, D. M., \& Fogel, A. (2009). A longitudinal investigation of maternal touching across the first 6 months of life: Age and context effects. Infant Behavior and Development, 32, 344-349.

Kagan, J. (1997). Conceptualizing psychopathology: The importance of developmental profiles. Developmental Psychopathology, 9, 321-334.

Kalin, N. H. (1999). Primate models of understanding human aggression. Journal of Clinical Psychiatry 60(Suppl 15), 29-32.

Katz, M., Liu, C., Schaer, M., Parker, K. J., Ottet, M. C., Epps, A., . . Lyons, D. M. (2009). Prefrontal plasticity and stress inoculation-induced resilience. Developmental Neuroscience, 31(4), 293-299.

Keltner, D. (2009). Born to be good: The science of a meaningful life. New York, NY: Norton. Klaus, M. H., \& Kennell, J. H. (1976/1983). Maternal-infant bonding: The impact of early separation or loss on family development. St. Louis, MO: C. V. Mosby. 
Kochanska, G. (2002). Mutually responsive orientation between mothers and their young children: A context for the early development of conscience. Current Directions in Psychological Science, 11(6), 191-195. doi:10.1111/1467-8721.00198

Konner, M. (2005). Hunter-gatherer infancy and childhood: The !Kung and others. In B. Hewlett \& M. Lamb (Eds.), Hunter-gatherer childhoods: Evolutionary, developmental and cultural perspectives (pp. 19-64). New Brunswick, NJ: Transaction.

Konner, M. (2010). The evolution of childhood. Cambridge, MA: Belknap Press.

Konner, M., \& Worthman, C. (1980). Nursing frequency, gonadal function and birth spacing among !Kung hunger-gatherers. Science, 207, 788-791.

Kramer, M. S., Chalmer, S. B., Hodnett, E. D., Sevkovskaya, Z., Dzikovich, I., Shapiro, S., ... . Helsing, E. (2001). Promotion of Breastfeeding Intervention Trial (PROBIT): A randomized trial in the Republic of Belarus. Journal of the American Medical Association, 285(4), 413-420.

Kramer, M. S., \& Kakuma, R. (2004). The optimal duration of exclusive breastfeeding: A systematic review. Advanced Experimental Medical Biology, 554, 63-77.

Kroes, R. A., Burgdorf, J. S., Schmidt, M. E., Panksepp, J., Beinfeld, M. C., \& Moskal, J. R. (2008). Uncovering the molecular basis of positive affect using rough-and-tumble play in rats: A role for insulin-like growth factor. Society for Neuroscience Annual Meeting, Washington, DC, November 7, 2008.

Ladd, C. O., Owens, M. J., \& Nemeroff, C. B. (1996). Persistent changes in corticotropinreleasing factor neuronal systems induced by maternal deprivation. Endocrinology, 137, 1212-1218. 
Lanius, R., Vermetten, E., \& Pain, C. (2010). The impact of early life trauma on health and disease: The hidden epidemic. New York, NY: Cambridge University Press.

Lansing, J. S., Watkins, J. C., Hallmark, B., Cox, M. P., Karafet, T. M., Sudoyo, H., \& Hammer, M. F. (2008). Male dominance rarely skews the frequency distribution of Y chromosome haplotypes in human populations. Proceedings of the National Academy of Sciences of the United States of America, 105, 11645-11650.

Lauritzen, L., Hansen, H. S., Jørgensen, M. H., \& Michaelsen, K. F. (2001). The essentiality of long chain n-3 fatty acids in relation to development and function of the brain and retina. Progressive Lipid Research, 40, 1-94.

Lavelli, M., \& Poli, M. (1998). Early mother-infant interaction during breast- and bottle-feeding. Infant Behavior and Development, 21, 667-684.

LeDoux, J. E. (1996). The emotional brain. New York, NY: Simon and Schuster.

Lester, B. M., Masten, A., \& McEwen, B. (Eds.). (2007). Resilience in children. Annals of the New York Academy of Sciences (Vol. 1094). New York, NY: Wiley-Blackwell.

Levine, R. A., Dixon, S., LeVine, S. E., Richman, A., Keefer, C., Liederman, P. H., \& Brazelton, T. B. (1994). Child care and culture: Lessons from Africa. New York, NY: Cambridge University Press.

Levine, S. (2005). Developmental determinants of sensitivity and resistance to stress. Psychoneuroendocrinology, 30(10), 939-946.

Lewis, T., Amini, F., \& Lannon, R. (2000). A general theory of love. New York, NY: Vintage.

Liu D, Diorio J, Tannenbaum B, Caldji C, Francis D, Freedman A, Sharma S, Pearson D, Plotsky PM, Meaney MJ (1997). Maternal care, hippocampal glucocorticoid receptors, and hypothalamic-pituitary-adrenal responses to stress, Science, 277(5332),1659-1662. 
Liu, W.F., Laudert, S., Perkins, B., MacMillan-York, E., Martin, S., \& Graven, S. for the NIC/Q 2005 Physical Environment Exploratory Group. (2007) The development of potentially better practices to support the neurodevelopment of infants in the NICU. Journal of Perinatology, 27, S48-S74.

Lumsden, C. J., \& Wilson, E. O. (1981). Genes, mind, and culture: The coevolutionary process. Cambridge, MA: Harvard University Press.

Lupien, S. J., McEwen, B. S., Gunnar, M. R., \& Heim, C. (2009). Effects of stress throughout the lifespan on the brain, behaviour and cognition. Nature, 10, 434-445.

MacDonald, G., \& Jensen-Campbell, L. A. (Eds.). (2011). Social pain: Neuropsychological and health implications of loss and exclusion. Washington, DC: American Psychological Association.

Marshall, R. E., Porter, F. L., Rogers, A. G., Moore, J., Anderson, B., \& Boxerman, S. B. (1982). Circumcision II: Effects on mother-infant interaction. Early Human Development, 7, $367-374$.

Martin, L. J., Woo, J. G., Geraghty, S. R., Altaye, M., Davidson, B. S., Banach, W., ... Morrow, A. L. (2006). Adiponectin is present in human milk and is associated with maternal factors. American Journal of Clinical Nutrition, 83, 1106-1111.

McDowell, M. M., Wang, C.-Y., \& Kennedy-Stephenson, J. (2008). Breastfeeding in the United States: Findings from the National Health and Nutrition Examination Survey, 19992006. Data Brief Number 5. Hyattsville, MD: National Center for Health Statistics.

McEwen, B. S. (2007). Physiology and neurobiology of stress and adaptation: Central role of the brain. Physiological Review, 87, 873-904. 
McGilchrist, I. (2009). The master and his emissary: The divided brain and the making of the western world. New Haven, CT: Yale University Press.

McGowan, P. O., Sasaki, A., D’Alessio, A. C., Dymov, S., Labonté, B., Szyf, M., ... Meaney, M. J. (2009). Epigenetic regulation of the glucocorticoid receptor in human brain associates with childhood abuse. Nature Neuroscience, 12, 342-348.

McKenna, J., Ball, H., \& Gettler, L. (2007). Mother-infant cosleeping, breastfeeding and sudden infant death syndrome: What biological anthropology has discovered about normal infant sleep and pediatric sleep medicine. Yearbook of Physiological Anthropology, 50, 133161.

McKenna, J., \& McDade, T. (2005). Why babies should never sleep alone: A review of the cosleeping controversy in relation to SIDS, bedsharing and breast feeding. Paediatric Respiratory Reviews, 6(2), 134-152.

McKenna, J. J., Mosko, S., Richard, C., Drummond, S., Hunt, L., Cetal, M., \& Arpaia, J. (1994). Mutual behavioral and physiological influences among solitary and co-sleeping motherinfant pairs: Implications for SIDS. Early Human Development, 38, 182-201.

Merzenich, M. M., Wright, B., Jenkins, W., Xerri, C., Byl, N., Miller, S., \& Tallal, P. (1996). Cortical plasticity underlying perceptual, motor and cognitive skill development: Implications for neurorehabilitation. Cold Spring Harbor Symposium on Quantitative Biology, 61, 1-8.

Michaelsen, K. F., Lauritzen, L., Jørgensen, M. H., \& Mortensen, E. L. (2003). Breast-feeding and brain development. Scandinavian Journal of Nutrition, 47(3), 147-151.

Millennium Ecosystem Assessment. (2005). Ecosystems and human well-being: Synthesis. Washington, DC: Island Press. 
Miller, E., \& Almon, J. (2009). Crisis in the kindergarten—why children need to play in school. College Park, MD: Alliance for Childhood.

Morelius, E., Theodorsson, E., \& Nelson, N. (2005). Salivary cortisol and mood and pain profiles during skin-to-skin care for an unselected group of mothers and infants in neonatal intensive care. Pediatrics, 116, 1105-1113.

Mortensen, E. L., Michaelsen, K. F., Sanders, S. A., \& Reinisch, J. M. (2002). The association between duration of breastfeeding and adult intelligence. Journal of the American Medical Association, 297, 2365-2371.

Moszkowski, R. J., Stack, D. M., Girouard, N., Field, T. M., Hernandez-Reif, M., \& Diego, M. (2009). Touching behaviors of infants of depressed mothers during normal and perturbed interactions. Infant Behavior and Development, 32, 183-194.

Nadel, J., \& Muir, R. (Eds.). (2005). Emotional development. Oxford: Oxford University Press.

Narvaez, D. (2008). Triune ethics: The neurobiological roots of our multiple moralities. New Ideas in Psychology, 26, 95-119.

National Institute of Child Health and Human Development, Early Child Care Research Network. (2003). Does amount of time spent in child care predict socioemotional adjustment during the transition to kindergarten? Child Development, 74, 976-1005.

National Institute of Child Health and Human Development, Early Child Care Research Network. (2004). Affect dysregulation in the mother-child relationship in the toddler years: Antecedents and consequences. Developmental Psychopathology, 16, 43-68.

Nelson, E. E., \& Panksepp, J. (1998). Brain substrates of infant-mother attachment: Contributions of opioids, oxytocin, and norepinephrine. Neuroscience and Biobehavioral Reviews, 22, 437-452. 
Newburg, D. S., \& Walker, W. A. (2007). Protection of the neonate by the innate immune system of developing gut and of human milk. Pediatric Research, 61(1), 2-8.

Oddy, W. H., Kendall, G. E., Li, J., Jacoby, P., Robinson, M., de Klerk, N. H., ... Stanley, F. J. (2010). The long-term effects of breastfeeding on child and adolescent mental health: A pregnancy cohort study followed for 14 years. Journal of Pediatrics, 156, 568-574.

Organization for Economic Cooperation and Development. (2009). Doing better for children. Paris: OECD Publishing.

Orosz, S. E., \& Bradshaw, G. A. (2007). Avian neuroanatomy revisited: From clinical principles to avian cognition. Veterinary Clinics Exotic Animals Practice, 10, 775-802.

Panksepp, J. (1981). Brain opioids: A neurochemical substrate for narcotic and social dependence. In S. Cooper (Ed.), Progress in theory in psychopharmacology (pp. 149_ 175). London: Academic.

Panksepp, J. (1998). Affective neuroscience: The foundations of human and animal emotions. New York, NY: Oxford University Press.

Panksepp, J. (2001). The long-term psychobiological consequences of infant emotions:

Prescriptions for the 21st century. Infant Mental Health Journal, 22, 132-173.

Panksepp, J. (2003). Neuroscience: Feeling the pain of social loss. Science, 302(5643), 237-239.

Panksepp, J. (2005). Affective consciousness: Core emotional feelings in animals and humans. Consciousness and Cognition, 14, 19-69.

Panksepp, J. (2007). Can PLAY diminish ADHD and facilitate the construction of the social brain. Journal of the Canadian Academy of Child and Adolescent Psychiatry, 10, 57-66. Panksepp, J. (2008). Carving “natural” emotions: “Kindly” from bottom-up but not top-down. Journal of Theoretical and Philosophical Psychology, 28, 395-422. 
Panksepp, J. (2009). Primary process affects and brain oxytocin. Biological Psychiatry, 65, 725727.

Panksepp, J. (2010). The basic affective circuits of mammalian brains: Implications for healthy human development and the cultural landscapes of ADHD. In C. M. Worthman, P. M. Plotsky, D. S. Schechter, \& C. A. Cummings (Eds.), Formative experiences: The interaction of caregiving, culture, and developmental psychobiology (pp. 470-502). New York, NY: Cambridge University Press.

Panksepp, J., \& Biven, L. (2011). The archaeology of mind: Neuroevolutionary origins of human emotions. New York, NY: Norton.

Panksepp, J., \& Harro, J. (2004). The future of neuropeptides in biological psychiatry and emotional psychopharmacology: Goals and strategies. In J. Panksepp (Ed.), Textbook of biological psychiatry (pp. 627-660). New York, NY: Wiley.

Panksepp, J., Siviy, S., \& Normansell, L. A. (1984). The psychobiology of play: Theoretical and methodological perspectives. Neuroscience and Biobehavioral Reviews, 8, 465-492.

Panksepp, J., \& Watt, J. (2011). Why does depression hurt? Ancestral primary-process separation-distress (PANIC) and diminished brain reward (SEEKING) processes in the genesis of depressive affect. Psychiatry, 74, 5-14.

Papousek, H., \& Papousek, M. (1992). Beyond emotional bonding: The role of preverbal communication in mental growth and health. Infant Mental Health Journal, 13, 43-53.

Parham, P. (2004). The immune system. New York, NY: Garland Publishing.

Peisner-Feinberg, E., Bernier, K., Bryant, D., \& Maxwell, K. (2000). Family child care in North Carolina. Chapel Hill, NC: Frank Porter Graham Child Development Institute.

Pellis, S. M., \& Pellis, V. C. (2009). The playful brain. Oxford: Oneworld Publications. 
Perry, B. D., Pollard, R., Blakely, T., Baker, W., \& Vigilante, D. (1995). Childhood trauma, the neurobiology of adaptation and 'use-dependent' development of the brain: How “states” become “traits.” Infant Mental Health Journal, 16(4), 271-291.

Porges, S. W. (2007). The polyvagal perspective. Biological Psychology, 74, 116-143.

Porter, C. L. (2003). Coregulation in mother-infant dyads: Links to infants’ cardiac vagal tone. Psychological Reports, 92, 307-319.

Potegal, M., \& Einon, D. (1989). Aggressive behaviors in adult rats deprived of playfighting experiences as juveniles. Developmental Psychobiology, 22, 159-172.

Powell, D., Fixen, D., \& Dunlop, G. (2003). Pathways to service utilization: A synthesis of evidence relevant to young children with challenging behavior. Tampa, FL: University of South Florida: Center for Evidence-Based Practice: Young Children with Challenging Behavior.

Prescott, J. W. (1996). The origins of human love and violence. Pre- and Perinatal Psychology Journal, 10(3), 143-188.

Propper, C., Moore, G. A., Mills-Koonce, W. R., Halpern, C. T., Hill-Soderlund, A. L., Calkins, S. D., ... Cox, M. (2008). Gene-environment contributions to the development of infant vagal reactivity: The interaction of dopamine and maternal sensitivity. Child Development, 79(5), 1377-1394.

Raver, C. C., \& Knitze, J. (2002). Ready to enter: What research tells policymakers about strategies to promote social and emotional school readiness among three- and four-yearold children. New York, NY: National Center for Children in Poverty.

Reddy, V. (2008). How infants know minds. Cambridge, MA: Harvard University Press. 
Richman, A., Miller, P., \& LeVine, R. (1992). Cultural and educational variations in maternal responsiveness. Developmental Psychology, 28, 614-621.

Roughgarden, J., \& Song, (in press). Incentives in the family I: The family firm, an evolutionary/economic theory for parent-offspring relations. In D. Narvaez, K. Valentino, A. Fuentes, J. McKenna, \& P. Gray, Ancestral Landscapes in Human Evolution: Culture, Childrearing and Social Wellbeing. New York: Oxford University Press.

Sagi, A., van Ijzendoorn, M., Aviezer, O., Donnell, F., Koren-Karie, N., Joels, T., \& Harel, Y. (1995). Attachments in a multiple-caregiver and multiple-infant environment: The case of the Israeli kibbutzim. In E. Waters (Ed.), Caregiving, cultural, and cognitive perspectives on secure-base behavior. Monographs of the Society for Research in Child Development, Vol. 60, (pp. 71-91). Chicago: University of Chicago Press.

Sanchez, M. M., Ladd, C. O., \& Plotsky, P. M. (2001). Early adverse experience as a developmental risk factor for later psychopathology. Development and Psychopathology, 13(3), 419-449.

Scanlon, K. S., Grummer-Strawn, L., Shealy, K. R., Jefferds, M. E., Chen, J., Singleton, J. A., \& Philip, C. M. (2007). Breastfeeding trends and updated national health objectives for exclusive breastfeeding_-United States, birth years 2000_2004. Morbidity and Mortality Weekly Report, 56(30), 760-763.

Schore, A. N. (1994). Affect regulation and the origin of the self. Hillsdale, NJ: Erlbaum.

Schore, A. N. (1997). Early organization of the nonlinear right brain and development of a predisposition to psychiatric disorders. Development and Psychopathology, 9, 595-631.

Schore, A. N. (2000). Attachment and the regulation of the right brain. Attachment and Human Development, 2, 23-47. 
Schore, A. N. (2001a). The effects of early relational trauma on right brain development, affect regulation, and infant mental health. Infant Mental Health Journal, 22, 201-269.

Schore, A. N. (2001b). Effects of a secure attachment relationship on right brain development, affect regulation, and infant mental health. Infant Mental Health Journal, 22, 7-66.

Schore, A. N. (2002). Dysregulation of the right brain: A fundamental mechanism of traumatic attachment and the psychopathogenesis of posttraumatic stress disorder. Australian and New Zealand Journal of Psychiatry, 36, 9-30.

Schore, A. N. (2003). Affect dysregulation and disorders of the self. New York, NY: Norton.

Schore, A. N. (2005). Attachment, affect regulation, and the developing right brain: Linking developmental neuroscience to pediatrics. Pediatrics in Review, 26, 204-211.

Schore, A. N. (2009). Attachment trauma and the developing right brain: Origins of pathological dissociation. In P. F. Dell \& J. A. O'Neil (Eds.), Dissociation and the dissociative disorders: DMS-V and beyond (pp. 107-141). New York: Routledge.

Scott, E., \& Panksepp, J. (2003). Rough-and-tumble play in human children. Aggressive Behavior, 29(6), 539-551.

Sheldon, K. M., Kashdan, T. B., \& Steger, M. F. (Eds.). (2011). Designing positive psychology: Taking stock and moving forward. New York, NY: Oxford University Press.

Siviy, S., \& Panksepp, J. (2011). In search of neurobiological substrates for social playfulness in mammalian brain. Neuroscience and Biobehavioral Reviews. doi:10.1016/j.neubiorev.2011.03.006

Slusser, W., \& Powers, N. G. (1997). Breastfeeding update 1: Immunology, nutrition, and advocacy. Pediatrics in Review, 18, 111-119. 
Smith, T. W., \& MacKenzie, J. (2006). Personality and risk of physical illness. Annual Review of Clinical Psychology, 2, 435-467.

Spinka, M., Newberry, R. C., \& Bekoff, M. (2001). Mammalian play: Training for the unexpected. Quarterly Review of Biology, 76, 141-168.

Stam, R., Akkermans, L. M., \& Wiegant, V. M. (1997). Trauma and the gut: Interactions between stressful experience and intestinal function. Gut, 40, 704-709.

Suomi, S. J. (2006). Risk, resilience, and gene x environment interactions in rhesus monkeys. Annals of the New York Academy of Sciences, 1094, 52-62.

Swain, J. E., Loberbaum, J. P., Kose, S., \& Strathearn, L. (2007). Brain basis of early parentinfant interactions: Psychology, physiology, and in vivo functional neuroimaging studies. Journal of Child Psychology and Psychiatry, 48, 262-287.

Swain, J. E., Tasgin, E., Mayes, L. C., Feldman, R., \& Leckman, J. F. (2008). Cesarean delivery affects maternal brain response to own baby cry. Journal of Child Psychology and Psychiatry, 9, 1042-1052.

Szajnberg, N., Goldenberg, A., \& Hatari, U. (2010). Early trauma, later outcome: Results from longitudinal studies and clinical observations. In R. Lanius, E. Vermetten, \& C. Pain (Eds.), The impact of early life trauma on health and disease: The hidden epidemic (pp. 33-42). New York, NY: Cambridge University Press.

Szyf, M., Weaver, I., \& Meaney, M. (2007). Maternal care, the epigenome and phenotypic differences in behavior. Reproductive Toxicology, 24(1), 9-19.

Szyf, M., McGowan, P., \& Meaney, M. J. (2008). The social environment and the epigenome. Environmental and Molecular Mutagenesis, 49, 46-60. 
Tannock, M. T. (2008). Rough and tumble play: An investigation of the perceptions of educators and young children. Early Childhood Education Journal, 35, 357-361.

Teicher, M. (2002). Scars that won't heal: The neurobiology of child abuse. Scientific American, 286(3), 68-75.

Textor, R. B. (1967). A cross-cultural summary. New Haven, CT: HRAF Press.

Thoman, E. B. (2006). Co-sleeping, an ancient practice: Issues of the past and present, and possibilities for the future. Sleep Medicine Review, 10, 407-417.

Thomas, E. M. (1959). The harmless people. New York, NY: Knopf.

Trevarthen, C. (2005). Action and emotion in development of the human self, its sociability and cultural intelligence: Why infants have feelings like ours. In J. Nadel and D. Muir (Eds.), Emotional development (pp. 61-91). Oxford: Oxford University Press.

Trevathan, W. R. (2011). Human birth: An evolutionary perspective. New York, NY: Aldine de Gruyter.

Tronick, E. (2007). The neurobehavioral and social-emotional development of infants and children. New York, NY: W. W. Norton.

Turnbull, C. M. (1961). The forest people. New York, NY: Simon and Schuster.

Uher, R., \& McGuffin, P. (2008). The moderation by the serotonin transporter gene of environmental adversity in the aetiology of mental illness: Review and methodological analysis. Molecular Psychiatry, 13(2), 131-146.

UNICEF. (2007). Child poverty in perspective: An overview of child well-being in rich countries, a comprehensive assessment of the lives and well-being of children and adolescents in the economically advanced nations. Report Card 7. Florence, Italy: United Nations Children’s Fund Innocenti Research Centre. 
U.S. Department of Health and Human Services, Substance Abuse and Mental Health Services Administration. (1999). Mental health: A report of the Surgeon General. Rockville, MD: Center for Mental Health Services, National Institutes of Health, National Institute of Mental Health.

Uvnas-Moberg, K. (1997). Physiological and endocrine effects of social contact. Annals of the New York Academy of Sciences, 15(807), 146-163.

Van den Berg, C. L., Hol, T., van Ree, J. M., Spruijt, B. M., Everts, H., \& Koolhaas, J. M. (1999). Play is indispensable for an adequate development of coping with social challenges in rats. Developmental Psychobiology, 34, 129-138.

Van Izjzendoorn, M., Sagi, A., \& Lambermon, M. (1992). The multiple caretaker paradox: Data from Holland and Israel. In R. C. Pianta (Ed.), Beyond the parents: The role of other adults in children's lives: New directions for child development, 57 (pp. 5-24). San Francisco, CA: Jossey-Bass.

Vanderschuren, L. J., Niesink, R. J., \& Van Ree, J. M. (1997). The neurobiology of social play behavior in rats. Neuroscience and Biobehavioral Reviews, 21, 309-326.

Vermeer, H. J., \& van Ijzendoorn, M. H. (2006). Children’s elevated cortisol levels at daycare: A review and meta-analysis. Early Childhood Research Quarterly, 21(3), 390-401.

Wagner, M. (2006). Born in the USA: How a broken maternity system must be fixed to put women and children first. Berkeley, CA: University of California Press.

Walker, M. (1993). A fresh look at the risks of artificial infant feeding. Journal of Human Lactation, 9(2), 97-107. 
Watt, D. F., \& Panksepp, J. (2009). Depression: An evolutionarily conserved mechanism to terminate separation-distress? A review of aminergic, peptidergic, and neural network perspectives. Neuropsychoanalysis, 11, 5-48.

Weaver, I. C., Szyf, M., \& Meaney, M. J. (2002). From maternal care to gene expression: DNA methylation and the maternal programming of stress responses. Endocrine Research, 28, 699.

West-Eberhard, M. J. (2003). Developmental plasticity and evolution. New York, NY: Oxford University Press.

Woolley, A. W., Chabris, C. F., Pentland, A., Hashmim, N., \& Malone, T. W. (2010). Evidence for a collective intelligence factor in the performance of human groups. Science, 330, 686-688.

World Health Organization and World Organization of Family Doctors. (2008). Integrating mental health into primary care: A global perspective. Geneva and London: Author.

Worthman, C. M., Plotsky, P. M., Schechter, D. S., \& Cummings, C. A. (Eds.). (2010). Formative experiences: The interaction of caregiving, culture, and developmental psychobiology. New York, NY: Cambridge University Press.

Yehuda, S., Rabinovitz, S., \& Mostofsky, D. I. (1999). Essential fatty acids are mediators of brain biochemistry and cognitive functions. Journal of Neuroscience Research, 56, 565570.

Zinken, J., Knoll, M., \& Panksepp, J. (2008). Universality and diversity in the vocalization of emotions. In K. Izdebski (Ed.), Emotions in the human voice, Vol. 1. Foundations (pp. 185-202). San Diego, CA: Plural Publishing. 
Zito, J., Safer, D., dos Ries, S., Gardener, J., Boles, M., \& Lynch, F. (2000). Trends in prescribing psychotropic medications to preschoolers. Journal of the American Medical Association, 282, 1025-1030.

Zubieta, J. K., Ketter, T. A., Bueller, J. A., Xu, Y., Kilbourn, M. R., Young, E. A., \& Koeppe, R. A. (2003). Regulation of human affective responses by anterior cingulate and limbic and mu-opioid neurotransmission. General Psychiatry, 60(11), 1037-1172. 